\title{
Finance and Growth: Evidence from the ARF Countries
}

${ }^{a}$ Rudra P. Pradhan, Vinod Gupta School of Management, Indian Institute of Technology Kharagpur, WB 721302, India. Email: rudrap@ vgsom.iitkgp.ernet.in (Corresponding Author)

${ }^{b}$ Mak B. Arvin, Department of Economics, Trent University, Peterborough, Ontario K9J 7B8,

Canada. Email: marvin@trentu.ca

'Sahar Bahmani, Department of Economics, University of Wisconsin-Parkside, Kenosha, Wisconsin 53144, USA. Email: bahmani@uwp.edu

${ }^{d}$ John H. Hall, Department of Financial Management, University of Pretoria, Pretoria 0028, Republic of South Africa. E-mail: john.hall@up.ac.za

${ }^{e}$ Neville R. Norman, Department of Economics, University of Melbourne, Victoria 3053, Australia. Email:

n.norman@unimelb.edu.au; Department of Economics, University of Cambridge, Cambridge CB3 9DD, UK. E-mail: nrn1v@econ.cam.ac.uk

\section{Highlights}

- We assess the causal relationship between economic growth, and four different types of financial development.

- The empirical investigation follows ASEAN Regional Forum countries between 1991 and 2012.

- We use a panel vector autoregressive model for detecting the direction of causality between these variables.

- The study demonstrates both unidirectional and bidirectional causality between these variables. 


\begin{abstract}
This paper examines the relationships between economic growth and four different types of financial development in ASEAN Regional Forum (ARF) countries over the period 1991-2011. Using principal component analysis (PCA) to construct development indices, and a panel vector auto-regressive model to test for Granger causalities, the study demonstrates unidirectional and bidirectional causality between the variables. The study enhances understanding of the interrelationship between the variables, combining different strands of the literature, and investigating countries previously neglected in this context. The paper recommends making banking more accessible to residents without bank accounts in ARF countries and promoting stock market development to facilitate access to investment capital in order to enhance economic growth.
\end{abstract}

Keywords: Financial development, economic growth, PCA, Granger causality, ARF countries

JEL Classification: O43, O16, E44, E31 


\section{Background of the Study}

In the last twenty years or so, most countries have adopted new development strategies that prioritize the modernization of their financial sector and the link of that sector to economic growth. The $\mathrm{ASEAN}^{1}$ regional forum countries (commonly known as the ARF countries) are no exception. Since the end of the 1980s, most ARF countries have promoted their own financial development, for instance, by reducing government intervention in national financial sectors, by privatizing banks, or by increasing the level of financial globalization ${ }^{2}$ (financial openness). In order to increase financial globalization, these countries have increased capital account liberalization and increased openness to capital flows. Financial globalization has significantly enhanced stability among industrialized countries. Clearly, financial globalization is a matter of considerable policy relevance, especially for major economies that have recently been taking steps to open up their capital accounts. Among developing economies, several are in the early stages of financial globalization and they are facing numerous on-going policy decisions about the timing and pace of further integration. The stakes for such policy decisions are high because financial globalization is often blamed for many damaging economic crises. When it comes to the policy implications of financial globalization, there is enormous variation of approaches and experiences across countries.

It is anticipated that financial development policies would promote economic growth through, inter alia, higher mobilization of savings or increased home and foreign investment (Reinhart and Tokatlidis, 2003). However, if such policies are to be effective, there needs to be a proven causal relationship between financial and real sectors (Gries $e t$ al., 2009).

The present paper focuses on whether financial development has actually influenced economic growth in a sample of seventeen ARF countries, and whether a policy focus on financial sector development is conducive to fostering economic development. Hence, we test the causality between financial development and economic growth, capturing different linkages by disaggregating financial sector development into four sub-

\footnotetext{
${ }^{1}$ ASEAN stands for the Association of South East Asian Nations.

${ }^{2}$ Financial globalization is an effective tool for achieving high outward-oriented development (see, for instance, Khan and Khan, 2003). Financial globalization has taken place in these countries in different forms over time. The two most important dimensions of this process are diversification and offshoring. The first one refers to the increase in foreign assets and liabilities in countries' portfolios, while the second one relates to the allocation of financial activities to the international markets, namely, to where transactions take place regardless of who holds the assets (see Ceballos et al., 2012; Hoekman and Kostecki, 2001).
} 
categories: banking sector development, stock market development, bond market development, and insurance market development.

Our study makes four contributions to the existing literature on the finance-growth nexus. Firstly, we combine different strands of the finance literature. Secondly, we deploy four composite indices of financial sector development, namely the composite index of banking sector development (CBSD), the composite index of stock market development (CSMD), the composite index of bond market development (CBMD), and the composite index of insurance market development (CIMD). Thirdly, we test for panel Granger causality, which is less prone to the misspecifications that often occur when testing causality between different subsectors of financial development and economic growth. Fourthly, we distinguish between the short-run and long-run causalities between various financial development indices and per capita economic growth.

The remainder of this paper is structured as follows: Section 2 provides an overview of financial development and economic growth; Section 3 provides a literature review on the connection between banking sector development, stock market development, bond market development, insurance market development, and economic growth; Section 4 highlights the research questions and the proposed hypotheses; Section 5 presents the data structure, sample selection, and the variables, followed by Section 6 which outlines our empirical model. The results are presented in Section 7, and the final section, Section 8, concludes with a summary and a discussion of the policy implications of our results.

\section{An overview of Financial Development and Economic Growth}

The level of financial development is one of the most important variables identified by the empirical growth literature as being correlated with economic growth performance across countries (see, for instance, Levine and Zervos, 1998; Graff, 2003; Calderon and Liu, 2003; Beck and Levine, 2004; Boulila and Trabelsi, 2004; Naceur and Ghazouani, 2007; Ang, 2008; Banos et al., 2011; Bojanic, 2012; Gochoco-Bautista et al., 2014; Jedidia et al., 2014; Ngare et al., 2014; Peia and Roszbach, 2015; Pradhan et al., 2015; Samargandi et al., 2015). The rate and level of financial development is a challenge for developing countries, as slow development can prevent such countries from taking full advantage of technology transfers, causing some of these countries to diverge from the growth rate of the world production frontier (Aghion et al., 2005; Menyah et al., 2014). Fung (2009) contends that poor countries with a weakened financial system are trapped in a vicious cycle, where low levels of financial development lead to low economic 
performance, and, conversely, low economic performance leads to low financial development. An inadequately supervised financial system may be crisis-prone, with potentially devastating effects (Moshirian and $\mathrm{Wu}, 2012$ ). The inverse is also true: an efficient financial system provides better financial services, which enables an economy to increase its growth rate (King and Levine, 1993a; Bencivenga et al., 1995; Esso, 2010). Financial development is not only pro-growth, but it is also pro-poor, suggesting that financial development helps poor citizens to catch up with the rest of the economy as it grows (Demirguc-Kunt and Levine, 2009). Furthermore, the endogenous growth theory, as articulated by Greenwood and Jovanovic (1990) and Bencivenga and Smith (1991) and others, stresses that financial development is a strategic factor that fosters long-run economic growth, because financial development, along with advancement, is able to facilitate economic growth through various channels. These channels are (a) supplying information about possible investments, so as to allocate capital efficiently; (b) supervising firms and exerting corporate governance; (c) diversifying risk; (d) mobilizing/pooling savings; (e) facilitating an exchange of goods and services; and (f) managing technology transfer (Garcia and Liu, 1999; Levine, 2005; Zhang et al., 2012).

Not surprisingly, the relationship between financial development ${ }^{3}$ and economic growth has been an important area of discussion among researchers and policy-makers (see, for instance, King and Levine, 1993a, 1993b; Thornton, 1994; Beck et al., 2000; Levine et al., 2000; Levine, 2003; Wachtel, 2003; Nieuwerburgh et al., 2006; Rashid, 2008; Tsouma, 2009; Bangake and Eggoh, 2011; Chow and Fung, 2011; Herwartz and Walle, 2014). However, it is still unclear what the roles and levels of cointegration and causality are among various subsectors of financial development, such as development in the banking sector, stock market, bond market and insurance market.

Development economics studies four types of relationships: firstly, the link between banking sector development and economic growth (Christopoulos and Tsionas, 2004; Tang, 2005; Moshirian and Wu, 2012; Menyah et al., 2014; Pradhan et al., 2014b); secondly, the link between stock market development and economic growth (Akinlo and Akinlo, 2009; Kar et al., 2011; Pradhan et al., 2013a; Pradhan et al., 2014a), thirdly, the

\footnotetext{
${ }^{3}$ Financial development is defined in terms of the aggregate size of the financial sector, its sectorial composition, and a range of attributes of individual sectors that determine their effectiveness in meeting users' requirements. The evaluation of financial structure should cover the roles of the key institutional players, including the central bank, commercial and merchant banks, saving institutions, development financial institutions, insurance companies, mortgage entities, pension funds, the stock market, and other financial market institutions (International Monetary Fund, 2005). Hence, financial development includes development in the banking sector, stock market, bond market and insurance market.
} 
link between bond market development and economic growth (Fink et al., 2006a, 2006b; Matei, 2013; Puente-Ajovin and Sanso-Navarro, 2015; Pradhan et al., 2016), and fourthly, the link between insurance market development and economic growth (Avram et al., 2010; Han et al., 2010; Chen et al., 2012; Lee et al., 2013; Pradhan et al., 2015).

In the broad spectrum of 'financial development', banking sector development, stock market development, bond market development and insurance market development are the main forces that can lead to high economic growth in a country. It has been argued in a subset of the finance-growth literature that development of the banking sector, stock market, bond market, and insurance market can cause each other. While policy-makers may differ on the degree to which these financial-sector developments contribute to economic growth, they generally concur that all the sub-sectors do in fact matter. As a result, many countries have adopted development strategies that prioritize development in their banking sector, stock market, bond market, and insurance market. In the present paper, we follow these sub-categories of financial development and their links to economic growth in the context of ARF countries.

\section{Review of the Literature}

Financial development is one of the keys to economic growth (Levine, 1997). The connection between the two has been the focus of a vast body of theoretical and empirical research since the seminal work of Schumpeter (1911) first appeared. A number of studies have examined the effect of financial development and economic growth using an array of techniques, such as cross-sectional, time series, panel data, and firm-level studies (King and Levine, 1993a, 1993b; Demetriades and Luintel, 1996; Levine, 2003; Beck and Levine, 2004; Dritsakis and Adamopoulos, 2004; Beck et al., 2004; Fung, 2009; Hsueh et al., 2013; Pradhan et al., 2013a; Chang et al., 2013; Gochoco-Bautista et al., 2014; Herwartz and Walle, 2014; Jedidia et al., 2014; Ngare et al., 2014; Peia and Roszbach, 2015; Uddin et al., 2014; Samargandi et al., 2015).

Empirical evidence from previous studies has demonstrated the presence of a positive long-run association between the various indicators of financial development and economic growth. In general, all of these papers suggest that a well-developed financial system is growth-enhancing, and hence consistent with the proposition of "more finance, more growth" (Law and Singh, 2014). At the same time, focus on causality between financial development and economic growth (the finance-growth link) has elicited considerable interest amongst economists in recent years. Subsequently, there have been numerous, and similar, studies in this regard for both developed and developing countries. 
While most of these studies have confirmed the existence of a causal relationship running from financial development to economic growth (Rousseau and Wachtel, 2000; Enisan and Olufisayo, 2009; Hassan et al., 2011; Pradhan et al., 2013b; Menyah et al., 2014), a few studies have also failed to find evidence of causality from financial development to economic growth (Lucas, 1988; Stern, 1989; Eng and Habibullah, 2011; Mukhopadhyay et al., 2011). Hence, the existing empirical studies on the relationship between financial development and economic growth do not provide conclusive evidence on the nature and direction of this relationship, and currently there is no consensus among economists about the nature of this relationship. In sum, the four most important possible relationships that have been emphasized in the financial literature on the causal link between financial development and economic growth are the unidirectional financial development-led growth hypothesis (the SLH - supply-leading hypothesis of finance and growth), the unidirectional growth-led financial development hypothesis (the DFH - demandfollowing hypothesis of finance and growth), the bidirectional causality between finance and growth hypothesis (the FBH - feedback hypotheses between finance and growth, where both lead each other simultaneously), and the no causality between finance and growth hypothesis (the NEH - neutrality hypotheses between finance and growth, where neither is seen to cause the other). These four hypotheses are equally applicable to all four subsectors of finance and economic growth. Next, we address the literature focusing on these four hypotheses.

A number of studies have demonstrated the validity of the "supply-leading hypothesis" view, where unidirectional causality from financial development (development of the banking sector, the stock market, the bond market, or the insurance market or a combination of these) to economic growth is present, for example, studies by Enisan and Olufisayo (2009), Jalil et al. (2010), Wu et al. (2010), Kar et al. (2011), Chaiechi (2012), Chen et al. (2012), Hsueh et al. (2013), Lee et al. (2013), Matei (2013), Alhassan and Fiador (2014), Menyah et al. (2014), Pradhan et al. (2014a), Pradhan et al. (2014b), and Puente-Ajovin and Sanso-Navarro (2015). According to this view, financial development contributes to economic growth through two main channels: first, by raising the efficiency of capital accumulation and, in turn, the marginal productivity of capital (Goldsmith, 1969) and, second, by raising the savings rate, and thus the investment rate (Shaw, 1973).

In contrast to the "supply-leading hypothesis" view, Demetriades and Hussein (1996), Liang and Teng (2006), Ang and McKibbin (2007), Liu and Sinclair (2008), Odhiambo 
(2008, 2010), Panopoulou (2009), Kar et al. (2011) and Puente-Ajovin and SansoNavarro (2015) claim evidence in favour of the "demand-following hypothesis" view, where causality runs from economic growth to financial development. According to this view, as the economy expands, the demand for financial services increases, leading to the growth of these services.

Studies such as those of Huang et al. (2000), Craigwell et al. (2001), Hassapis and Kalyvitis (2002), Al-Yousif (2002), Caporale et al. (2004), Dritsakis and Adamopoulos (2004), Wolde-Rufael (2009), Lee and Chang (2009), Hou and Cheng (2010), Cheng (2012), Pradhan et al. (2015) and Puente-Ajovin and Sanso-Navarro (2015) claim to have uncovered the "feedback hypothesis", whereby the causality runs in both directions.

Finally, studies such as those by Lucas (1988), Stern (1989), Fink et al. (2006 a,b), Mukhopadhyay et al. (2011), Pradhan et al. (2013b), and Puente-Ajovin and SansoNavarro (2015) claim to exhibit the "neutrality hypothesis", where financial market development and economic growth are seen as independent of each other. It is evident from the literature that the evidence on the direction of causality between these two variables needs more advanced statistical analysis than the literature has previously afforded it. Table 1 presents a synopsis of research on the causal nexus between various subsectors (aspects) of financial development and economic growth.

\section{$<<$ Insert Table 1 here $>>$}

\section{Research Questions and Proposed Hypotheses}

The present paper is not intended to be a comprehensive study of all of the determinants of economic growth. Rather, it examines the nature of the relationship between economic growth, banking sector development, stock market development, bond market development, and insurance market development - all together, using a panel vector auto-regressive model to detect the direction of causality between the variables. Among other things, our study obviously combines several strands of the literature. We test whether banking sector development, stock market development, bond market development, and insurance market development Granger-cause economic growth, and whether they Granger-cause each other. In sum, we propose to test ten hypotheses, based upon the structure of our study. These hypotheses are summarized in Figure 1.

\section{$<<$ Insert Figure 1 here $>>$}




\section{Sample Selection, Data Structure, and Variables}

Our study involves the ARF countries, a group of countries that have not yet been studied in this literature. ${ }^{4}$ We consider three samples of countries, covering 17 countries in total. Our first sample consists of the eight countries among the ARF-26 that are recognized as ARF-members and observer countries (AMOC), namely Indonesia, Malaysia, Pakistan, the Philippines, Singapore, Sri Lanka, Thailand, and Vietnam. The second sample consists of the nine countries among the ARF-26 that are recognized as ARF-dialogue partner countries (ADPC) ${ }^{5}$, namely Australia, Canada, China, India, Japan, the Korean Republic, New Zealand, the Russian Federation, and the United States. The third sample consists of all 17 ARF countries (TARC) that were included in AMOC and ADPC. Analyzing all 25 member nations is not possible due to unavailability of usable data on eight countries over the period of our study. We deploy annual time series data over the period from 1991 to 2011. The data are abstracted and adapted from two main sources, namely (a) World Development Indicators, the World Bank and (b) Sigma Economic Research \& Consulting, Switzerland.

The variables used in the present study are banking sector development, stock market development, bond market development, insurance market development, and per capita economic growth.

Banking sector development is defined as a process of improvements in the quantity, quality, and efficiency of banking services. This process involves the interaction of many activities, and consequently cannot be captured by a single measure (Gregorio and Guidotti, 1995; Levine and Zervos, 1996; Rousseau and Wachtel, 1998; Beck and Levine, 2004; Liang and Teng, 2006; Naceur and Ghazouani, 2007; Abu-Bader and Abu-Qarn, 2008; Gries et al., 2009; Banos et al., 2011; Pradhan et al., 2013b). Hence, the present study employs four commonly used measures of banking sector development, namely broad money supply (BBRM), domestic credit provided by the banking sector (BDCB),

\footnotetext{
${ }^{4}$ The 26 ARF countries comprise of 25 member nations plus the European Union, which is represented by the President of the European Council and by the European Central Bank. The member countries are Australia, Bangladesh, Brunei, Burma, Cambodia, Canada, China, East Timor, the European Union, India, Indonesia, Japan, the Korean Republic, Laos, Malaysia, Mongolia, New Zealand, Pakistan, Papua New Guinea, the Philippines, the Russian Federation, Singapore, Sri Lanka, Thailand, the United States, and Vietnam.

${ }^{5}$ In this sub-category we observe only nine countries, which are used for our analysis. The European Union, the tenth member of this group, is excluded because it is not a country.
} 
domestic credit provided by the financial sector (BDCF) and domestic credit provided to the private sector $(\mathrm{BDCP})$.

Stock market development is defined as a process of improvements in the quantity, quality and efficiency of stock market services. It also involves the interaction of many activities and cannot be captured by a single measure (Rousseau and Wachtel, 1998; Wongbangpo and Sharma, 2002; Caporale et al., 2004; Zhu et al., 2004; Darrat et al., 2006; Rousseau and Xiao, 2007; Rousseau, 2009; Cooray, 2010; Hou and Cheng, 2010; Kar et al., 2011; Cheng, 2012; Pradhan et al., 2013a). The present study deploys four commonly used measures of stock market development, namely stock market capitalization (SMAC), stocks traded (STRA), stocks turnover ratio (STUR), and the number of listed companies in the stock market (SNLC).

Bond market development is defined as a process of improvements in the quantity, quality, and efficiency of debt services. This process involves the interaction of many activities, and consequently cannot be captured by a single measure (Fink et al., 2006a, 2006b; Matei, 2013; Puente-Ajovin and Sanso-Navarro, 2015). Hence, the present study employs four commonly-used measures of bond market development, namely domestic private debt securities (BDPT), domestic public debt securities (BDPU), international private debt securities (IDPT), and international public debt securities (IDPU).

Insurance market development is defined as a process of improvements in the quantity, quality and efficiency of insurance services. It also involves the interaction of many activities and cannot be captured by a single measure (Webb et al., 2005; Arena, 2008; Han et al., 2010; Chen et al., 2013; Lee et al., 2013; Pradhan et al., 2015). The present study deploys four commonly used measures of insurance market development, namely life insurance density (ILID), non-life insurance density (INID), life insurance premium (ILIP), and non-life insurance premium (INIP).

Table 2 presents a detailed definition of these variables.

\section{$<$ Insert Table 2 here $>>$}

Our analysis is based on the use of four composite indices of financial development, namely the composite index of banking sector development (CBSD), the composite index of stock market development (CSMD), the composite index of bond market development (CBMD), and the composite index of insurance market development (CIMD). Principal component analysis (PCA) has been used to arrive at these four indices. PCA is based on a linear transformation of the individual variables so that they are orthogonal to each other 
(Lewis-Beck, 1994). This kind of analysis is ideally suited for the purposes of the present study as it maximizes the variance, rather than minimizes the least square distance.

In general, PCA transforms data into new variables (principal components) that are not correlated. The PCA entails a few structured steps: constructing a data matrix, creating standardized variables, calculating a correlation matrix, determining eigen values (to rank principal components) and eigenvectors, selecting principal components (based on stopping rules), and interpreting the results (Hosseini and Kaneko, 2012).

The use of PCA to construct a composite index, as in our analysis, is well-documented in several papers (see, for instance, Gries et al., 2009; Herwartz and Walle, 2014; Menyah et al., 2014; Pradhan et al., 2014a). ${ }^{6}$ For the present study, the eigen vectors and principal components of these four indices are shown in Table 3.

\section{$<<$ Insert Table 3 here $>>$}

We define economic growth as the growth rate of per capita income (denoted by PGDP) - with income defined as real gross domestic product. All four indices and the economic growth rate were converted into their natural logarithms for estimation purposes.

\section{Analytical Framework and Estimation Procedure}

This study uses a multivariate framework to explore the finance-growth nexus for a panel of 17 ARF countries. We utilize the following regression model to describe the long-run relationship among CBSD, CSMD, CBMD, CIMD, and PGDP:

$$
P G D P_{i t}=\mu_{0} C B S D_{i t}^{\mu 1 i} C S M D_{i t}^{\mu 2 i} C B M D_{i t}^{\mu 3 i} C^{2}{ }^{2} D_{i t}^{\mu_{i t}} e^{\varepsilon_{i t}}
$$

The logarithmic transformation of equation (1) is given by

$$
\begin{aligned}
& P G D P_{i t}=\mu_{0 P G D P i t}+\mu_{1 P G D P i} C B S D_{i t}+\mu_{2 P G D P i} C S M D_{i t}+\mu_{3 P G D P i} C B M D_{i t}+ \\
& \mu_{4 P G D P i} C I M D_{i t}+\varepsilon_{\text {PGDPit }}
\end{aligned}
$$

where $i=1,2 \ldots, \mathrm{N}$ represents each country in the panel; $t=1,2 \ldots ., \mathrm{T}$ refers to the time period; and $\varepsilon_{i t}$ refers to the independently and normally distributed random variables for all $i$ and $t$ with zero means and finite heterogeneous variances $\left(\sigma_{i}^{2}\right)$.

The parameters $\beta_{1}, \beta_{2}, \beta_{3}$, and $\beta_{4}$ represent the long-run elasticity estimates of PGDP in respect of CBSD, CSMD, CBMD and CIMD, respectively. The task is to estimate the

\footnotetext{
${ }^{6}$ Hosseini and Kaneko (2012) and Pradhan et al. (2014a) discuss the procedural details of the use of PCA.
} 
parameters in Equation (2) and conduct some panel tests on the causal nexus between these five variables. The study postulates that increases in banking sector, stock market, bond market, and insurance market activities can increase economic growth.

We deploy the following panel vector error-correction model (VECM) to consider the possible causal nexus among these five variables:

$$
\begin{aligned}
& {\left[\begin{array}{l}
\Delta \ln P G D P_{i t} \\
\Delta \ln C B S D_{i t} \\
\Delta \ln C S M D_{i t} \\
\Delta \ln C B M D_{i t} \\
\Delta \ln C I M D_{i t}
\end{array}\right]=\left[\begin{array}{l}
\eta_{1 j} \\
\eta_{2 j} \\
\eta_{3 j} \\
\eta_{4 j} \\
\eta_{5 j}
\end{array}\right]} \\
& +\sum_{k=1}^{q}\left[\begin{array}{l}
\mu_{11 i k}(L) \mu_{12 i k}(L) \mu_{13 i k}(L) \mu_{14 i k}(L) \mu_{15 i k}(L) \\
\mu_{21 i k}(L) \mu_{22 i k}(L) \mu_{23 i k}(L) \mu_{24 i k}(L) \mu_{25 i k}(L) \\
\mu_{31 i k}(L) \mu_{32 i k}(L) \mu_{33 i k}(L) \mu_{34 i k}(L) \mu_{35 i k}(L) \\
\mu_{41 i k}(L) \mu_{42 i k}(L) \mu_{43 i k}(L) \mu_{44 i k}(L) \mu_{45 i k}(L) \\
\mu_{51 i k}(L) \mu_{52 i k}(L) \mu_{53 i k}(L) \mu_{54 i k}(L) \mu_{55 i k}(L)
\end{array}\right]\left[\begin{array}{l}
\Delta \ln P G D P_{i t-k} \\
\Delta \ln C B S D_{i t-k} \\
\Delta \ln C S M D_{i t-k} \\
\Delta \ln C B M D_{i t-k} \\
\Delta \ln C I M D_{i t-k}
\end{array}\right] \\
& +\left[\begin{array}{c}
\gamma_{1 i} E C T_{i t-1} \\
\gamma_{2 i} E C T_{i t-1} \\
\gamma_{3 i} E C T_{i t-1} \\
\gamma_{4 i} E C T_{i t-1} \\
\gamma_{5 i} E C T_{i t-j}
\end{array}\right]+\left[\begin{array}{l}
\varepsilon_{1 i t} \\
\varepsilon_{2 i t} \\
\varepsilon_{3 i t} \\
\varepsilon_{4 i t} \\
\varepsilon_{5 i t}
\end{array}\right]
\end{aligned}
$$

where $\Delta$ is the first difference filter $(\mathrm{I}-\mathrm{L}) ; i$ represents country in the panel; $t$ represents time period; and $\varepsilon_{j i t}(\mathrm{j}=1, \ldots, 5)$ represents the random variable.

The ECTs are error-correction terms representing the long-run dynamics, while differenced variables represent the short-run dynamics between the variables. The model is meaningful only if the time series variables are integrated of order one, I (1) (i.e. if they achieve stationarity after being differenced once), and are cointegrated. If the variables used in Equation (2) are not cointegrated, the ECTs are removed in the estimation process. The study investigates short-run and long-run causal relationships among PGDP, CBSD, CSMD, CBMD and CIMD. The short-run causal relationship is detected through $F$ statistics and the significance of the changing lagged independent variables; the long-run causal relationship is measured through the significance of the $t$-statistics of the lagged ECTs. The first step under the VECM framework is determining the order of integration and nature of cointegration among the five variables. 
Hence, the testing procedures involve a total of four steps. The first is checking the unit root of each variable in order to determine the order of integration when a particular variable reaches its stationarity. The study uses five sets of unit root tests ${ }^{7}$ for this purpose.

The second step is checking the cointegration (identifying long-run cointegration relationships among these five variables). We use Pedroni's panel cointegration test ${ }^{8}$ (Pedroni, 2000) for this purpose.

Having confirmed the existence of cointegration of our panel, the next step is to estimate the associated long-run cointegration parameters. Although the ordinary least squares (OLS) estimators of the cointegrated vectors are super-convergent, their distribution is asymptotically biased and depends on nuisance parameters associated with the presence of serial correlation in the data (Pedroni, 2001). Many types of problems in time series analysis may also arise in panel data analysis. These problems tend to be more marked even in the presence of heterogeneity (Kao and Chiang, 2001). Hence, we used two different panel cointegration estimators, namely between-group fully modified OLS $\left(\right.$ FMOLS $\left.^{9}\right)$ and dynamic OLS (DOLS $\left.{ }^{10}\right)$. Both of these estimators provide consistent estimates of standard errors that can be used for inferences. According to Kao and Chiang (2000), both FMOLS and DOLS estimators have normal limiting properties. Consequently, in order to carry out tests on the cointegrated vectors, it is necessary to apply both FMOLS and DOLS to work out the estimates of cointegrating parameters.

Finally, on the basis of both unit root and cointegration findings, the last step is to estimate the panel VECM in order to infer the Granger causal relationship among the five variables - PGDP, CBSD, CSMD, CBMD and CIMD.

It should be noted that VECM estimation is very sensitive to lag selection. The Akaike Information Criterion (AIC) and the Schwartz-Bayes Information Criterion (SBC) have

\footnotetext{
${ }^{7}$ These include the Levine-Lin-Chu ' $t$-stat' (LLC; Levine et al., 2002), the Breitung ' $t$-stat' (BR; Breitung, 2000), Im-Pesaran-Shin ' $W$-stat' (IPS: Im et al., 2003), Augmented Dickey Fuller (ADF)-Fisher 'ChiSquare' and Phillips Perron (PP)-Fisher 'Chi-Square' panel unit root tests (Choi, 2001). These tests are detailed in several advanced econometric textbooks (see, for example, Enders, 2009) and are not described here due to space constraints.

${ }^{8}$ This test follows seven different cointegration statistics, which includes four individual panel statistics, namely the panel $v$-statistic, panel $\rho$-statistic, panel $t$-statistic (non-parametric) and panel $t$-statistic (parametric), and also three group statistics, namely the group $\rho$-statistic, group $t$-statistic (non-parametric) and group $t$-statistic (parametric). This test is discussed in several advanced econometric textbooks such as Enders (2009).

${ }^{9}$ FMOLS is a non-parametric approach that takes into account the possible correlation between the error term and the first differences of the regressor, as well as the presence of a constant term to deal with corrections for serial correlation (Pedroni, 2001).

${ }^{10}$ DOLS is a parametric approach that adjusts the errors by augmenting the static regression with leads, lags, and contemporaneous values of the regressor in first differences (Kao and Chiang, 2000).
} 
been used to fix the optimum lag selection. These criteria are widely used in advanced applied econometric studies.

\section{Empirical Results and Discussion}

The empirical investigation begins with unit root and cointegration between the five variables, namely, PGDP, CBSD, CSMD, CBMD, and CIMD. We present the results of our panel unit roots tests and panel cointegration tests in Tables 4 and 5, respectively.

The results of five panel unit root tests reveal that all five variables in this study (PGDP, CBSD, CSMD, CBMD, and CIMD) are non-stationary at their levels. However, all variables become stationary at their first differences. Therefore, we can conclude that all these time series variables are integrated of order one, I (1), over the period from 1991 to 2011. This finding is true for all three samples that we consider in this study, namely AMOC, ADPC, and TARC.

\section{$<<$ Insert Table 4 here $>>$}

After assessing the stationarity of the series by determining the order of integration I (d), we use co-integration testing to determine the presence or absence of a long-run equilibrium relationship among the variables. The null hypothesis of no cointegration is examined, based on seven different cointegration test statistics (as mentioned above).

From the seven test statistics of the Pedroni panel cointegration test, it can be seen that two statistics are statistically significant at a $1 \%$ level (Case 1 and Case 2 in Table $5)$. Hence, the null hypothesis of no cointegration can be rejected. It can thus be concluded that these variables are cointegrated, indicating the presence of a long-run equilibrium relationship between banking sector development, stock market development, bond market development, insurance market development, and per capita economic growth. This finding holds for all three samples we considered.

\section{<< Insert Table 5 here $>>$}

Having established the status of the unit root and cointegration, the next step is to estimate the associated long-run cointegration parameters. Here, we are most interested in checking the nature of the relationship among these variables, more specifically, 
whether it is positive or negative. The findings show that all four financial indicators (CBSD, CSMD, CBMD and CIMD) exercise a significant positive impact on PGDP in the long run. The presence of a highly significant positive impact of CBSD, CSMD, CBMD and CIMD on PGDP for the 17 ARF countries implies that all financial indicators play a critical role in boosting per capita economic growth in the economies of ARF countries. The results of this section are not reported here due to space constraints, but are available upon request from the corresponding author.

Engle and Granger (1987) established that when variables are cointegrated, an errorcorrection model necessarily describes the data-generating process. Consequently, on the basis of the unit root test and cointegration test results, we deployed the panel Granger causality test, based on panel VECMs, to determine the causal relations amongst these five variables. We want to detect how these variables cause each other in this particular cointegration framework, especially in the short and long run. The results of the Granger causality tests for all three samples are summarized in Table 6.

\section{$<$ Insert Table 6 here $>>$}

We first describe the long-run results, which are ascertained through examining the statistical significance of the lagged error-correction term. Table 6 shows that when $\triangle \mathrm{PGDP}$ is used as the dependent variable, the lagged error-correction terms (ECTs) are statistically significant at a 5\% level. This implies that economic growth tends to converge to its long-run equilibrium path in response to changes in its regressors: CBSD, CSMD, CBMD and CIMD. The significance of the $\mathrm{ECT}_{-1}$ coefficient in the $\triangle \mathrm{PGDP}$ equation in each of the three samples confirms the presence of a long-run equilibrium between PGDP and its determinants, namely banking sector development, stock market development, bond market development, and insurance market development. In other words, we can generally conclude that development in the financial sector Granger-causes per capita economic growth in the long run. This is true for all three samples that we consider (AMOC, ADPC, and TARC) from 1991 to 2011.

Therefore, the overall conclusion is that per capita economic growth is key in ARF countries and is significantly influenced by financial development through all its subsectors, namely the development of these countries' stock markets, banking sectors, bond markets and insurance markets. In addition to this finding, we also identify another fundamental long-run Granger causal relationship between these variables. Thus, when 
$\triangle \mathrm{CBMD}$ serves as the dependent variable, the lagged ECTs are statistically significant at a 5\% level. This indicates that per capita economic growth, and development in the banking sector, stock market, and insurance market Granger-cause bond market development in the long run. This is also true for all three samples that we considered (AMOC, ADPC, and TARC) over the period 1991 to 2011.

In contrast to the long-run Granger causality results, the second part of our discussion deals with the question of short-run Granger causality amongst these five sets of variables. These results, based on the values presented in Table 6, are summarized in Table 7 and are discussed below.

\section{<< Insert Table 7 here $>$}

The overall findings are the presence of unidirectional causality from per capita economic growth to banking sector development, and bidirectional causality between stock market development and per capita economic growth, between bond market development and per capita economic growth, and between insurance market development and per capita economic growth. However, in other situations, the results differ from sample to sample.

In ARF Member and Observer Countries (AMC), we have found evidence of unidirectional causality from banking sector development to bond market development [CBSD $\Rightarrow \mathrm{CBMD}]$, insurance market development to banking sector development $[\mathrm{CIMD}=>\mathrm{CBSD}]$, bond market development to stock market development $[\mathrm{CBMD}=>$ CSMD], and insurance market development to both stock market development and bond market development [CIMD $=>$ CSMD; CIMD $=>$ CBMD].

For ARF Dialogue Partner Countries (ADPC), we have uncovered evidence of bidirectional causality between insurance market development and bond market development [CIMD $\Leftrightarrow$ CBMD], and unidirectional causality from banking sector development to both bond market development and insurance market development $[\mathrm{CBSD}=>\mathrm{CSMD} ; \mathrm{CBSD}=>\mathrm{CIMD}]$, from stock market development to bond market development $[\mathrm{CBMD}<=\mathrm{CSMD}]$, and insurance market development to stock market development $[\mathrm{CIMD}=>\mathrm{CSMD}]$.

For ARF Countries combined (ATC), we have confirmed bidirectional causality between insurance market development and bond market development [CIMD $\Leftrightarrow$ CBMD] and between stock market development and bond market development [CBMD $<=$ CSMD]. In addition to these results, we also note unidirectional causality from 
banking sector development to insurance market development [CBSD $=>$ CIMD], and from insurance market development to stock market development [CIMD $=>$ CSMD].

In line with prior studies, our study distinguishes clearly between short-run and longrun causal relationships, and between financial development and per capita economic growth. The long-run causal results display a causal link between the two relationships in the long run, whereas short-run causal results show the adjustment dynamics between the variables in the short run.

We found uniform and robust results for the long-run equilibrium relationship amongst the variables, when per capita economic growth and bond market development serve as the dependent variable. Thus, it appears that in order to stimulate long-run per capita economic growth, it is important to stimulate development in the banking sector, stock market, bond market, and insurance market in the ARF countries. Similarly, to stimulate long-run bond market development, development in the banking sector, stock market, and insurance market as well as per capita economic growth should be encouraged in the ARF countries.

For short-run causal relationships, we find remarkable variations in results which are nonetheless consistent with earlier work in the different strands of this literature. We highlight some of these short-run results below.

Firstly, our result relating to whether per capita economic growth Granger-causes banking sector development supports the "demand-following hypothesis (DFH)" of the finance-growth nexus. This result appears in three of our samples (ADOC, ADPC, and TARC) and is consistent with the findings of Colombage (2009), Panopoulou (2009), Odhiambo (2010), Kar et al. (2011) and Pradhan et al. (2013b).

Secondly, our result relating to bidirectional causality between stock market development and per capita economic growth, bond market development and per capita economic growth, and insurance market development and per capita economic growth, supports the "feedback hypothesis $(F B H)$ " of the finance-growth nexus. This result appears in all three samples of our study and is consistent with the findings of Ward and Zurbruegg (2000), Fink et al. (2003), Zhu et al. (2004), Cheng (2012), Guochen and Wei (2012), and Puente-Ajovin and Sanso-Navarro (2015).

Thirdly, our findings relating to both unidirectional and bidirectional Granger causality between various financial development indicators (banking sector development, stock market development, bond market development, and insurance market development), support the "supply-leading hypothesis (SLH)", the "demand-following 
hypothesis (DFH)" and the "feedback hypothesis (FBH)" view between two particular sub-sectors of financial development. These results hold true in all three samples, consistent with the findings of Levine and Zervos (1998), Beck and Levine (2004), Hou and Cheng (2010), Cheng (2012) and Pradhan et al., (2014a). This case ensures the possibility of complementary (and/or substitute) roles between two sub-financial sectors in the process of achieving high economic growth.

\section{Conclusion and Policy Implications}

Understanding the policy implications of the nexus between banking sector development, stock market development, bond market development, insurance market development and per capita economic growth is important in both financial economics and in forming economic policies. We have established that more needs to be learned about the various connections among these five sets of variables. Earlier studies have examined the causal link amongst just a few of these variables. By contrast, our study examined the causal relationships between all these variables, studied simultaneously. That is, the causal link between two variables is considered in the presence of the residual variables.

This study has found that banking sector development, stock market development, bond market development, insurance market development, and per capita economic growth are cointegrated in the ARF countries. Most importantly, there is evidence that development in the banking sector, stock market, bond market, and insurance market matter in the determination of long-run per capita economic growth, although the set of statistically significant independent variables varies slightly by sample, due to the heterogeneity of the countries in each panel. Our results carry four policy implications.

Firstly, with regard to the relationship between banking sector development and economic growth nexus, the recommendation is that attention must be paid to policies that promote banking sector development. This calls for efficient allocation of financial resources, combined with sound regulation of the banking system. A sound banking system instils confidence among savers so that resources can be effectively mobilized to increase productivity in the economy. The banking system should be simplified and banking fees should be reduced for qualifying clients, so that barriers to entry of the banking sector are lowered, making banking activities more accessible to those members of a country's population who are currently excluded from engaging in banking and financial transactions. Moreover, banking products should be diversified in such a way 
that non-banking financial companies and non-financial institutions can enter the banking sector

Secondly, with regard to the relationship between stock market development and economic growth nexus, we recommend that a well-developed stock market is necessary in the ARF countries. A credible and reliable stock market system is indispensable in ensuring the smooth functioning of the financial system and in increasing the productivity of the economy, in line with the arguments presented by Levine (1991) and Yartey (2008). A well-developed stock market facilitates firms' raising debt and equity capital for investment, thereby enhancing economic growth and attracting foreign direct investment by multi-national corporations.

Thirdly, with regard to the relationship between bond market development and economic growth nexus, bond market development is desirable to facilitate more economic growth in these ARF countries. This, in turn, requires an efficient allocation of financial resources combined with sound assurances to bond market development (Felman et al., 2014; Gray et al., 2011). The development of the bond market can also be used to obtain more development in the banking sector, stock market, insurance market, and to achieve sustainable economic growth in the ARF countries.

Lastly, with regard to the relationship between insurance market development and economic growth nexus, insurance market development is desirable to facilitate more economic growth in the ARF countries. The development of the insurance sector can also be used to encourage greater development in the banking sector, stock market and bond market, and to achieve sustainable economic growth in the ARF countries. For instance, an active and competitive insurance sector can help these economies to stimulate savings, provide an alternate source of investment, reinforce the development of the banks, the stock market and the bond market, mitigate risks associated with volatility in capital inflows, and shift government burdens to support large pension schemes to employee insurance-supported retirement schemes.

If policy-makers want to stimulate per capita economic growth, they should stimulate development in the financial markets, while simultaneously fostering growth in the banking sector, stock market, bond market and insurance market. All the subsectors of financial market development should be considered as drivers of per capita economic growth given the significance of their respective roles. 
Acknowledgment: The authors have benefited from the useful comments of an anonymous referee of this journal. 


\section{References}

Abu-Bader, S. and Abu-Qarn, A. S. (2008). Financial Development and Economic Growth: Empirical Evidence from Six MENA Countries. Review of Development Economics, 12 (4): 803-817.

Aghion, P., Howit, P. and Mayer-Foulkes, D. (2005). The Effect of Financial Development on Convergence: Theory and Evidence. Quarterly Journal of Economics, 120 (1): 173222.

Akinlo A. E. and Akinlo O. O. (2009). Stock Market Development and Economic Growth: Evidence from Seven Sub-Sahara African Countries. Journal of Economics and Business, 61 (2): 162-171.

Alhassan, A.L. and Fiador, V. (2014). Insurance-growth nexus in Ghana: An autoregressive distributed lag cointegration approach. Review of Development Finance, 4 (2):83-96.

Al-Yousif, Y. K. (2002). Financial Development and Economic Growth: Another Look at the Evidence from Developing Countries. Review of Financial Economics, 11 (2): 131-150.

Ang, J. B. (2008). Survey of Recent Developments in the Literature of Finance and Growth. Journal of Economic Surveys, 22 (3): 536-576.

Ang, J. B. and McKibbin (2007). Financial Liberalization, Financial Sector Development and Growth: Evidence from Malaysia? Journal of Development Economics, 84 (1): 215-233.

Arena, M. (2008). Does Insurance Market Activity Promote Economic Growth? A Cross Country Study for Industrialized and Developing Countries. Journal of Risk and Insurance, 75 (4): 921-946.

Avram, K., Nguyen, Y. and Skully, M. (2010). Insurance and Economic Growth: a Cross Country Examination. Working Paper. Australian Centre for Financial Studies-Finsia Banking and Finance Conference, Australia.

Bangake, C. and Eggoh, J. C. (2011). Further Evidence on Finance-Growth Causality: A Panel Data Analysis. Economic Systems, 35 (2): 176-188.

Banos, J. L., Crouzille, C. M., Nys, E. and Sauviat, A. (2011). Banking Industry Structure and Economic Activities: A Regional Approach for the Philippines. Philippines Management Review, 18 (1): 97-113.

Beck, T. and Levine, R. (2004). Stock Markets, Banks, and Growth: Panel Evidence. Journal of Banking and Finance, 28 (3): 423-442.

Beck, T., Levine, R. and Loayza, N. (2000). Finance and Source of Growth. Journal of Financial Economics, 58 (1-2): 261- 300.

Beck, T., Demirgüç-Kunt, A., Maksimovic, V. (2004). Financial and Legal Constraints to Firm Growth: Does Size Matter? Journal of Finance, 60: 137-177.

Bencivenga, V. R. and Smith, B. D. (1991). Financial Intermediation and Endogenous Growth. Review of Economic Studies, 58 (2): 195-209.

Bencivenga, V. R., Smith, B. D. and Starr, R. M. (1995). Transaction Costs, Technological Choice, Endogenous Growth. Journal of Economic Theory, 67 (1): 53-117.

Bojanic, A. N. (2012). The Impact of Financial Development and Trade on the Economic Growth of Bolivia. Journal of Applied Economics, 15 (1): 51-70.

Boon, T. K. (2005). Do Commercial Banks, Stock Markets and Insurance Market Promote Economic Growth? An Analysis of the Singapore Economy. Working Paper, Nanyang Technological University, Singapore.

Boulila, G. and Trabelsi, M. (2004). Financial Development and Long Run Growth: Evidence from Tunisia: 1962-1997. Savings and Development, 28 (3): 289-314.

Breitung J. (2000). The local power of some unit root tests for panel data. In Badi H. Baltagi, Thomas B. Fomby, R. Carter Hill (ed.) Nonstationary Panels, Panel Cointegration, and Dynamic Panels (Advances in Econometrics, Volume 15), Emerald Group Publishing Limited, pp.161-177. 
Calderon, C. and Liu, L. (2003). The Direction of Causality between Financial Development and Economic Growth. Journal of Development Economics, 72 (1): 321- 334.

Caporale, G. M., Howells, P. G. and Soliman, A. M. (2004). Stock Market Development and Economic Growth: The Causal Linkage. Journal of Economic Development, 29 (1): 33 50.

Ceballos, F., Didier, T., and Schmukler, S. L. (2012). Finnacial Globalization in Emerging Countries: Diversification vs. Offshoring. ADBI Working Paper Series, No. 389. Asian Development Bank Institute, Tokyo.

Chaiechi, T. (2012). Financial Development Shocks and Contemporaneous Feedback Effect on Key Macroeconomic Indicators: A post Keynesian Time Series Analysis. Economic Modelling, 29 (2): 487-501.

Chang, T., Cheng, S. C., Pan, G. and Wu, T. P. (2013). Does Globalization Affect the Insurance Markets? Bootstrap Panel Granger Causality Test. Economic Modelling, 33 (1): 254-260.

Chen, P. F., Lee, C. C. and Lee, C. F. (2012). How Does the Development of Life Insurance Market affect Economic Growth? Some International Evidence. Journal of International Development, 24 (7): 865-893.

Chen, S. S., Cheng, S. C., Pan, G. and Wu, T. P. (2013). The Relationship between Globalization and Insurance Activities: A Panel Data Analysis. Japan and the World Economy, 28 (3): pp. 151-157.

Cheng, S. (2012). Substitution or complementary effects between banking and stock markets: Evidence from financial openness in Taiwan. Journal of International Financial Markets, Institutions and Money, 22 (3): 508-520.

Choi, I. (2001). Unit Root Tests for Panel Data. Journal of International Money and Finance, 20 (2): 249-272.

Chow, W. W. and Fung, M. K. (2011). Financial Development and Growth: A Clustering and Causality Analysis. Journal of International Trade and Economic Development, 35 (3): $1-24$.

Christopoulos, D. K. and Tsionas, E. G. (2004). Financial Development and Economic Growth: Evidence from Panel Unit Root and Cointegration Tests. Journal of Development Economics, 73 (1): 55-74.

Colombage, S. R. N. (2009). Financial Markets and Economic Performances: Empirical Evidence from Five Industrialized Countries. Research in International Business and Finance, 23 (3): 339-348.

Cooray, A. (2010). Do Stock Markets Lead to Economic Growth? Journal of Policy Modeling, 32 (4): 448-460.

Craigwell, R., Downes, D. and Howard, M. (2001). The Finance-Growth Nexus: A Multivariate VAR Analysis of a Small Open Economy. Savings and Development, 25 (2): 209-223.

Darrat, A. F., Elkhal, K. and McCallum, B. (2006). Finance and Macroeconomic Performance: Some Evidence from Emerging Markets. Emerging Markets Finance and Trade, 42 (3): 5-28.

Demetriades P. and Luintel (1996). Financial Development, Economic Growth and Banking Sector Controls: Evidence from India. The Economic Journal, 106 (435): 359-374.

Demetriades, P. O. and Hussein, K. A. (1996). Does Financial Development Cause Economic Growth? Timeseries Evidence from 16 Countries'. Journal of Development Economics 51(2): 387-411.

Demirguc-kunt, A. and Levine, R. (2009). Finance and Inequality: Theory and Evidence. Policy Research Working Paper Series, No. 4967. The World Bank, Washington DC. 
Dritsakis, N. and Adamopoulos, A. (2004). Financial Development and Economic Growth in Greece: An Empirical Investigation with Granger Causality Analysis. International Economic Journal, 18 (4): 547-559.

Enders, W. (2009). Applied Econometric Time Series. Wiley publications, New York.

Eng, Y. and Habibullah M. S. (2011). Financial Development and Economic Growth Nexus: Another look at the Panel Evidence from Different Geographical Regions. Bank and Bank Systems, 6 (1): 62-71.

Engle, R. F. and Granger, C. W. J. (1987). Cointegration and Error Correction: Representation, Estimation and Testing. Econometrica, 55(2): 251-276.

Enisan, A. A. and Olufisayo, A.O. (2009). Stock Market Development and Economic Growth: Evidence from Seven Sub-Saharan African Countries. Journal of Economics and Business, 61 (2): 162-171.

Esho, N., Kirievsky, A., Ward, D. and Zurbruegg, R. (2004). Law and the Determinants of Property-Causality Insurance. Journal of Risk and Insurance, 71 (2): 265-283.

Esso, L. J. (2010). Re-examining the Finance-Growth Nexus: Structural Break, Threshold Cointegration and Causality Evidence from the ECOWAS. Journal of Economic Development, 35 (3): 57-79.

Felman, J., Gray, S., Goswami, M., Jobst, A. A., Pradhan, M., Peiris, S. and Seneviratne, D. (2014). ASEAN-5 bond market development: Where does it stand? Where is it going? Asian Pacific Economic Literature, 28 (1): 60-75.

Fink, G., Haiss, P. and Histofrova, S. (2003). Bond Markets and Economic Growth. IEF $\begin{array}{lllll}\text { Working } & \text { Paper. } & \text { No. } & \text { p. } & 1-31 .\end{array}$ http://core.kmi.open.ac.uk/download/pdf/11007252.pdf.

Fink, G., Haiss, P. and Vuksic, G. (2006a). Contribution of Financial Market Segments at Different Stages of Development: Transition, Cohesion and Mature Economies Compared. Journal of Financial Stability, 5 (4): 431-455.

Fink, G., Haiss, P. and Vuksic, G. (2006b). Importance of Financial Sectors for Growth in Accession Countries. In (Liebscher, K., Christ, J., Mooslechner, P., and RitzbergerGrunwald, D. (Eds.), Financial Development, Integration and Stability, pp. 154-185. Edward Elgar, Cheltenham.

Fung, M. K. (2009). Financial Development and Economic Growth: Convergence or Divergence? Journal of International Money and Finance, 28 (1): 56-67.

Garcia, V. F. and Liu, L. (1999). Macroeconomic Determinants of Stock Market Development. Journal of Applied Economics, 11 (1): 29-59.

Gochoco-Bautista, M. S., Sotocinal, N. R. and Wang, J. (2014). Corporate Investments in Asian Markets: Financial Conditions, Financial Development, and Financial Constraints. World Development, 57 (3): 63-78.

Goldsmith, R, W. (1969). Financial structure and development. New Haven, CT: Yale University Press.

Graff, M. (2003). Finance Development and Economic Growth in Corporatist and Liberal Market Economies. Emerging Market Finance \& Trade, 39 (2): 47- 69.

Gray, S., Felman, J., Carvaja, A. and Jobst, A. A. (2011). Developing ASEAN-5 Bond Markets: What Needs to be Done? Asia Pacific Economic Literature, 28 (1): 76- 95.

Greenwood, J. and Jovanovic, B. (1990). Financial Development, Growth, and the Distribution of Income. Journal of Political Economy, 98 (5): 1076-1107.

Gregorio, J. D. and Guidotti, P. E. (1995). Financial Development and Economic Growth. World Development, 23 (3): 433-448.

Gries, T., Kraft, M. and Meierrieks, D. (2009). Linkages between Financial Deepening, Trade Openness, and Economic Development: Causality Evidence from Sub-Saharan Africa. World Development, 37 (12): 1849-1860. 
Guochen, P. and Wei, S. C. (2012). The relationship between insurance development and economic growth: A cross-region study for China. China International Conference on Insurance and Risk Management, July 18-21, 2012, Qingdao, China.

Han, L., Li, D., Moshirian, F., and Tian, L. (2010).Insurance Development and Economic Growth. The Geneva Papers on Risk and Insurance, 35 (2): 183-199.

Hassan, K. M., Sanchez, B. and Yu, J. (2011). Financial Development and Economic Growth: New Evidence from Panel Data. The Quarterly Review of Economics and Finance, 51 (1): 88-104.

Hassapis, C. and Kalyvitis, S. (2002). Investigating the Links between Growth and Stock Price Changes with Empirical Evidence from the G7 Economies. Quarterly Review of Economics and Finance, 42 (3): 543-575.

Herwartz, H. and Walle, Y. M. (2014). Determinants of the Link between Financial and Economic Development: Evidence from a Functional Coefficient Model. Economic Modelling, 37 (2): 417-427.

Hoekman, B. M. and Kostecki, M. M. (2001). The Political Economy of the World Trading System. Oxford Press, New York.

Hosseini, H. M. and Kaneko, S. (2012). Causality between Pillars of Sustainable Development: Global Stylized Facts or Regional Phenomena. Ecological Indicators, 14 (1): 197-201.

Hou, H. and Cheng, S. Y. (2010). The Roles of Stock Market in the Finance-Growth Nexus: Time Series Cointegration and Causality Evidence from Taiwan. Applied Financial Economics, 20 (12): 975-981.

Hsueh, S., Hu, Y. and Tu, C. (2013). Economic Growth and Financial Development in Asian Countries: A Bootstrap Panel Granger Causality Analysis. Economic Modelling, 32 (3): 294-301.

Huang, B., Yang, C. and Hu, J. W. (2000). Causality and Cointegration of Stock Markets among the United States, Japan, and the South China Growth Triangle. International Review of Financial Analysis, 9 (3): 281-297.

Im, K. S., Pesaran, M. H. and Shin, Y. (2003). Testing for Unit Roots in Heterogeneous Panels. Journal of Econometrics, 115 (1): 53- 74.

International Monetary Fund (2005). Indicators of Financial Structure, Development, and Soundness. Chapter $2 . \quad$ Online available at: http://www.imf.org/external/pubs/ft/fsa/eng/pdf/ch02.pdf.

Jalil, A., Feridun, M. and Ma, Y. (2010). Finance-Growth Nexus in China Revisited: New Evidence from Principal Components and ARDL Bounds Tests. International Review of Economics and Finance, 19 (2): 189-195.

Jedidia, K. B., Boujelbene, T. and Helali, K. (2014). Financial Development and Economic growth: New Evidence from Tunisia. Journal of Policy Modelling, 36 (5): 883-898.

Kao, C. and Chiang, M. H. (2000). On the Estimation and Inference of a Cointegrated Regression in Panel Data. Advances in Econometrics: Nonstationary Panels, Panel Cointegration and Dynamic Panels. 15 (1): 179-222.

Kar, M., Nazlioglu, S. and Agir, H. (2011). Financial Development and Economic Growth Nexus in the MENA Countries: Bootstrap Panel Granger Causality Analysis. Economic Modelling, 28 (1-2): 685-693.

Khan, S. M. and Khan, Z. S. (2003). Asian Economic Integration: A Perspective on South Asia. Journal of Asian Economics. 13: 767-785.

King, R. and Levine, R. (1993a). Finance and Growth: Schumpeter Might be Right. The Quarterly Journal of Economics, 108 (3): 717-737.

King, R. and Levine, R. (1993b). Finance, Entrepreneurship and Economic Growth: Theory and Evidence. Journal of Monetary Economics, 32 (3): 513-542. 
Kugler, M. and Ofoghi, R. (2005). Does Insurance Promote Economic Growth? Evidence from the UK. Paper presented at the Money Macro and Finance (MMF) Research Group Conference. United Kingdom.

Law, S. H. and Singh, N. (2014). Does Too Much Finance Harm Economic Growth? Journal of Banking and Finance, 41 (3): 36-44.

Lee, C. and Chang, C. (2009). FDI, Financial Development and Economic Growth: International Evidence. Journal of Applied Economics, 12 (2): 249-271.

Lee, C., Huang, W. and Yin, C. (2013). The Dynamic Interactions among the Stock, Bond and Insurance Markets. North American Journal of Economics and Finance, 26 (3): 2852.

Levine, A., Lin, C. F. and Chu, C. S. (2002). Unit Root Tests in Panel Data: Asymptotic and Finite Sample Properties. Journal of Econometrics, 108 (1): 1-24.

Levine, R. (1991). Stock Markets, Growth, and Tax Policy. Journal of Finance, 46 (4): 14451465.

Levine, R. (1997), Financial Development and Economic Growth: Views and Agenda, Journal of Economic Literature, 35 ((20): 688-726.

Levine, R. (2003). More on Finance and Growth: More Finance, More Growth? Federal Reserve Bank of St. Louis Review, 85 (6): 31-46.

Levine, R. (2005). Finance and Growth: Theory and Evidence. In P. Aghion and S. Durlauf (EDs.), Handbook of Economic Growth. Elsevier Science, Amsterdam.

Levine, R. and Zervos, S. (1996). Stock Market Development and Long-run Growth. World Bank Economic Review, 10 (2): 323-339.

Levine, R. and Zervos, S. (1998). Stock Markets, Banks and Economic Growth. American Economic Review, 88 (3): 537-558.

Levine, R., Loayza, N. and Beck, T. (2000). Financial Intermediation and Growth: Causality Analysis and Causes. Journal of Monetary Economics, 46 (1): 31-77.

Lewis-Beck, M. (1994). Factor Analysis and Related Techniques. Sage Publications, New Delhi.

Liang, Q. and Teng, J. (2006). Financial Development and Economic Growth: Evidence from China. China Economic Review, 17 (4): 395-411.

Liu, X. and Sinclair, P. (2008). Does the Linkage between Stock Market Performance and Economic Growth Vary across Greater China. Applied Economics Letters, 15 (7): 505508.

Lucas, R. (1988). On the Mechanics of Economic Development. Journal of Monetary Economics, 22 (1): 3- 42.

Masih, A. M. M. and Masih, R. (1999). Are Asian Stock Market Fluctuations Due Mainly to Intra-Regional Contagion Effects? Evidence Based on Asian Emerging Stock Markets. Pacific Basin Finance Journal, 7 (3-4): 251-282.

Matei, I. (2013). Empirical Analysis of the Links between Sovereign Bond Markets and Economic Growth for European Non- EMU Countries. Banks and Bank Systems, 8 (3): 58-71.

Menyah, K., Nazlioglu, S. and Wolde-Rufael, Y. (2014). Financial Development, Trade Openness and Economic Growth in African Countries: New Insights from a Panel Causality Approach. Economic Modelling, 37 (2): 386-394.

Moshirian, F. and Wu, Q. (2012). Banking Industry Volatility and Economic Growth. Research in International Business and Finance, 26 (3): 428-442.

Mukhopadhyay, B., Pradhan, R. P. and Feridun, M. (2011). Finance-growth Nexus Revisited for Some Asian countries. Applied Economics Letters, 18 (6): 1527- 1530. 
Naceur, S. B. and Ghazouani, S. (2007). Stock Markets, Banks, and Economic Growth: Empirical Evidence from the MENA Region. Research in International Business and Finance, 21 (2): 297-315.

Ngare, E., Nyamongo, E. M. and Misati, R. N. (2014). Stock Market Development and Economic Growth in Africa. Journal of Economics and Business, 74 (1): 24-39.

Nieuwerburgh, S. V., Buelens, F. and Cuyvers, L. (2006). Stock Market Development and Economic Growth in Belgium. Explorations in Economic History, 43 (1): 13-38.

Nishat, M. and Saghir, A. (1991). The Stock Market and Pakistan Economy -1964-87. Savings and Development, 15 (2): 131-146.

Odhiambo, N. M. (2008). Financial Development in Kenya: A Dynamic Test of the Financeled Growth Hypotheses. Economic Issues, 13 (2): 21-36.

Odhiambo, N. M. (2010). Finance-Investment-Growth Nexus in South Africa: An ARDL Bounds Testing Procedure. Economic Change Restructuring, 43 (3): 205-219.

Owusu, E. L. and Odhiambo, N. M. (2014). Financial Liberalization and Economic Growth in Nigeria: An ARDL- bounds Testing Approach. Journal of Economic Policy Reform, 17 (2): 164-177.

Panopoulou, E. (2009). Financial Variables and Euro Area Growth: A Non-parametric Causality Analysis. Economic Modelling, 26 (6): 1414-1419.

Pedroni, P. (2000). Fully Modified OLS for Heterogeneous Cointegrated Panels. Advanced in Econometrics, 15 (1): 93-130.

Pedroni, P. (2001). Purchasing Power Parity Tests in Cointegrated Panels. Review of Economics and Statistics, 83 (4): 727-731.

Peia, O. and Roszbach, K. (2015). Finance and Growth: Time Series Evidence on Causality. Journal of Financial Stability, 19 (1): 105-118.

Pradhan, R. P. (2013). The Determinants of Long-run Finance Development: The ARDL Bound Testing Approach. Journal of Social and Management Sciences, 52 (1): 43-63.

Pradhan, R. P., Arvin, M. B. and Norman, N. R. (2015). Insurance development and the finance-growth nexus: Evidence from 34 OECD countries. Journal of Multinational Financial Management, 31 (1): 1-22.

Pradhan, R. P., Arvin, M. B., Bele, S. and Taneja, S. (2013a). The Impact of Stock Market Development on Inflation and Economic Growth of 16 Asian Countries: A Panel VAR Approach. Applied Econometrics and International Development, 13 (1): 203-220.

Pradhan, R. P., Arvin, M. B., Norman, N. R. and Hall, J. H. (2014a). The Dynamics of Banking Sector and Stock Market Maturity and the Performance of Asian Economies. Journal of Economic and Administrative Sciences, 30 (1): 16-44.

Pradhan, R. P., Arvin, M. B., Bennett, S. E., Nair, M. and Hall, J. H. (2016). Bond Market Development, Economic Growth and Other Macroeconomic Determinants: Panel VAR Evidence. Asia-Pacific Financial Markets, 23 (2): 175-201

Pradhan, R. P., Arvin, M. B., Norman, N. R. and Nishigaki, Y. (2014b). Does Banking Sector Development Affect Economic Growth and Inflation? A Panel Cointegration and Causality Approach. Applied Financial Economics, 24 (7): 465-480.

Pradhan, R. P., Dasgupta, P. and Samadhan, B. (2013b). Finance Development and Economic Growth in BRICS: A Panel Data. Journal of Quantitative Economics, 11 (2): 308-322.

Pradhan, R. P., Zaki, D. B., Chatterjee, D. and Maradona, R. P. and Dash, S. (2015). Can Stock Market Development Boost Economic Growth and Trade Openness? Cointegration, Granger Causality and Forecast Error Variance Decomposition Tests for ARF Countries. Prajnan, 64 (1): 9- 28.

Puente-Ajovin, M. and Sanso-Navarro, M. (2015). Granger causality between Debt and Growth: Evidence from OECD Countries. International Review of Economics and Finance, 35: 66-77. 
Rashid, A. (2008). Macroeconomic Variables and Stock Market Performance: Testing for Dynamic Linkages with a Known Structural Break. Savings and Development, 32 (1): 77102.

Reinhart, C. M. and Tokatlidis, I. (2003). Financial Liberalization: The African Experience. Journal of African Economies. 12 (2): 53-88.

Rousseau, P. L. (2009). Share Liquidity, Participation, and Growth of the Boston Market for Industrial Equities, 1854-1897. Explorations in Economic History, 46 (2): 203-219.

Rousseau, P. L. and Wachtel, P. (2000). Banks, Stock Markets and China's Great Leap Forward. Emerging Markets Review, 8 (3): 206-217.

Rousseau, P. L. and Xiao, S. (2007). Equity Markets and Growth: Cross Country Evidence on Timing and Outcomes, 1980-1995. Journal of Banking and Finance, 24 (12): 19331957.

Samargandi, N., Fidrmuc, J. and Ghosh, S. (2015). Is the Relationship between Financial Development and Economic Growth Monotonic? Evidence from a Sample of MiddleIncome Countries. World Development, 68 (3): 66-81.

Schumpeter, J. A. (1911). The Theory of Economic Development. Harvard University Press, Cambridge, MA.

Shaw, E. S. (1973). Financial Deepening in Economic Development. Oxford University Press, New York.

Stern, N. H. (1989). The Economics of Development: A Survey. Economic Journal, 99 (397): 597- 685.Tang, T. C. (2005). An Examination of the Causal Relationship between Bank Lending and Economic Growth: Evidence from ASEAN. Savings and Development, 29(3): 313-343.

Tang, T. C. (2005). An Examination of the Causal Relationship between Bank Lending and Economic Growth: Evidence from ASEAN. Savings and Development, 29 (3): 313343.

Thornton, J. (1994). Financial Deepening and Economic Growth: Evidence from Asian Economies. Savings and Development, 18 (1): 41-51.

Tsouma, E. (2009). Stock Returns and Economic Activity in Nature and Emerging Markets. Quarterly Review of Economics and Finance, 49 (2): 668-685.

Uddin, G. S., Shahbaz, M., Arouri, M. and Teulon, F. (2014). Financial Development and Poverty Reduction Nexus: A cointegration and causality Analysis in Bangladesh. Economic Modelling, 36 (1): 405-412.

Wachtel, P. (2003). How Much Do We Really Know about Growth and Finance? Federal Reserve Bank of Atlanta Economic Review, 88 (1): 33-47.

Ward, D. and Zubruegg, R. (2000). Does Insurance Promote Economic Growth? Evidence from OECD Countries. Journal of Risk and Insurance, 67 (4): 489-506.

Webb, I.P., Grace, M.F., Skipper, H.D., (2005). The effect of banking and insurance on the growth of capital and output. SBS Revista De Termas Financieros, 2 (2): 1-32.

Wolde-Rufael, Y. (2009). Re-examining the financial development and economic growth nexus in Kenya. Economic Modelling, 26 (6): 1140-1146.

Wongbangpo, P. and Sharma, S. C. (2002). Stock Market and Macroeconomic Fundamental Dynamic Interactions: ASEAN-5 Countries. Journal of Asian Economics, 13 (1): 27-51.

Wu, J., Hou, H. and Cheng, S. (2010). The Dynamic Impacts of Financial Institutions on Economic Growth: Evidence from the European Union. Journal of Macroeconomics, 32 (3): 879-891.

Yartey, C. A. (2008). The Determinants of Stock Market Development in Emerging Economies: Is South Africa Different. IMF Working Paper, No. WP/ 08/ 32, pp. 1-31. International Monetary Fund, Washington DC. 
Zhang, J., Wang, L. and Wang, S. (2012). Financial Development and Economic Growth: Recent Evidence from China. Journal of Comparative Economics, 40 (3): 393-412.

Zhu, A., Ash, M. and Pollin, R. (2004). Stock Market Liquidity and Economic Growth: A Critical Appraisal of the Levine/ Zervos Model. International Review of Applied Economics, 18 (1): 63-71. 
Table 1. Summary of Studies on the Links between Different Aspect of Financial Development and Economic Growth

\begin{tabular}{|c|c|c|c|c|}
\hline Study & Sample & $\begin{array}{l}\text { Type } \\
\text { of } \\
\text { Mar } \\
\text { ket }\end{array}$ & $\begin{array}{l}\text { Period } \\
\text { studied }\end{array}$ & Main finding(s) \\
\hline Alhassan and Fiador (2014) & Ghana & $\mathrm{d}$ & $1990-2010$ & SLH \\
\hline Ang (2008) & Malaysia & $\mathrm{b}$ & $1960-2001$ & DFH \\
\hline Boon (2005) & Singapore & $\mathrm{d}$ & 1991-2002 & SLH \\
\hline Chen et al. (2012) & 60 countries & $\mathrm{d}$ & $1976-2005$ & SLH \\
\hline Cheng (2012) & Taiwan & $\mathrm{b}$ & 1973-2007 & $\mathrm{FBH}$ \\
\hline Chow and Fung (2011) & 69 countries & a & $1970-2004$ & $\mathrm{FBH}$ \\
\hline Enisan and Olufisayo (2009) & 7 Sub-Saharan Africa: & $\mathrm{b}$ & 1980-2004 & SLH \\
\hline Esho et al. (2004) & 44 countries & $\mathrm{d}$ & 1984-1998 & $\mathrm{DFH}$ \\
\hline Fink et al. (2003) & 10 European countrie: & $\mathrm{c}$ & 1994-2003 & SLH, FBH \\
\hline Fink et al. $(2006 a, b)$ & 15 European countrie: & $\mathrm{c}$ & 1994-2003 & SLH, DFH \\
\hline Guochen and Wei (2012) & China & $\mathrm{d}$ & 2006-2011 & SLH, DFH, FBH, NLH \\
\hline Hou and Cheng (2010) & Taiwan & $\mathrm{b}$ & $1971-2007$ & $\mathrm{FBH}$ \\
\hline Hsueh et al. (2013) & 10 Asian countries & $\mathrm{a}$ & $1980-2007$ & SLH \\
\hline Jalil et al. (2010) & China & $\mathrm{a}$ & 1977-2006 & SLH \\
\hline Kar et al. (2011) & 15 MENA countries & $a, b$ & $1980-2007$ & SLH, DFH \\
\hline Kolapo and Adaramola (2012) & Nigeria & $\mathrm{b}$ & $1990-2010$ & SLH \\
\hline Kugler and Ofoghi (2005) & United Kingdom & $\mathrm{d}$ & $1966-2003$ & DFH, FBH \\
\hline Lee et al. (2013) & 6 Developed countrie: & $\mathrm{d}$ & 1979-2007 & SLH \\
\hline Liu and Sinclair (2008) & China & $\mathrm{b}$ & $1973-2003$ & $\mathrm{DFH}$ \\
\hline Matei (2013) & 14 ENEMU countries & $\mathrm{c}$ & 2002-2012 & SLH \\
\hline Menyah et al. (2014) & 21 African countries & a & $1965-2008$ & SLH \\
\hline Odhiambo (2010) & South Africa & $\mathrm{a}$ & 1969-2006 & DFH \\
\hline Owusu and Odhiambo (2014) & Nigeria & $a, b$ & 1969-2008 & SLH \\
\hline Panopoulou (2009) & 5 countries & $a, b$ & $1995-2007$ & DFH \\
\hline Pradhan et al. (2015) & 34 OECD countries & $\mathrm{d}$ & $1988-2012$ & $\mathrm{FBH}$ \\
\hline Pradhan, Arvin et al. (2013) & 16 Asian countries & $\mathrm{b}$ & $1988-2012$ & SLH \\
\hline Pradhan, Arvin, Norman and Hall (2014) & Asian countries & a & $1960-2011$ & $\mathrm{FBH}$ \\
\hline Pradhan, Arvin, Norman and Nshigaki (20 & 15 Asian countries & $\mathrm{b}$ & 2011 & DFH \\
\hline Pradhan, Dasgupta and Samadhan (2013) & 16 Asian countries & $\mathrm{b}$ & 1988-2012 & SLH \\
\hline Puente-Ajovin and Sanso-Navarro (2015) & 16 OECD countries & $\mathrm{c}$ & 1980-2009 & SLH, DFH, FBH \\
\hline Ward and Zurbruegg (2000) & 9 OECD countries & $\mathrm{d}$ & 1961-1996 & DFH, FBH \\
\hline Webb et al. (2005) & 55 countries & $\mathrm{d}$ & 1980-1996 & SLH \\
\hline Wolde-Rufael (2009) & Kenya & a & $1966-2005$ & $\mathrm{FBH}$ \\
\hline Zhu et al. (2004) & 14 countries & $\mathrm{b}$ & 1995-2009 & $\mathrm{FBH}$ \\
\hline
\end{tabular}

Note 1: MENA: Middle East and North Africa region; OECD: Organization for Economic Co-operation and Development; ENEMU: European Non-EMU countries.

Note 2: As is evident, different studies focus on different aspects of financial development. a: signifies that results relate to the link between banking sector development and economic growth; b: signifies that results relate to the link between stock market development and economic growth; c: signifies that results relate to the link between bond market development and economic growth; d: signifies that results relate to the link between insurance market development and economic growth.

Note 3: DFH: results support the demand-following hypothesis; SLH: results support the supply-leading hypothesis; FBH: results support the feedback hypothesis; NLH: results support the neutrality hypothesis. 
Table 2. Definition of Financial Development Variables and Indices

Variable

Definition

\author{
Definition of Banking Sector Development Variables \\ BBRM Broad money supply, expressed as a percentage of gross domestic \\ product. \\ BDCB Domestic credit provided by the banking sector, expressed as a \\ percentage of gross domestic product. \\ BDCF Domestic credit provided by the financial sector, expressed as a \\ percentage of gross domestic product. \\ BDCP Domestic credit to the private sector, expressed as a percentage of \\ gross domestic product. \\ CBSD Composite index of banking sector development, using BBRM, \\ $\mathrm{BDCB}, \mathrm{BDCF}$, and BDCP.
}

Definition of Stock Market Development Variables

SMAC Market capitalization of listed companies, expressed as a percentage of gross domestic product.

STRA Stocks traded (total value), expressed as a percentage of gross domestic product.

STUR Stocks traded (turnover ratio), expressed as a percentage change in the turnover ratio in the stock market.

SNLC Number of listed companies in the stock market, expressed per 10,000 population.

CSMD Composite index of stock market development, using SMAC, STRA, STUR, and SNLC.

\title{
Definition of Bond Market Development Variables
}

BDPT

Domestic private debt securities, expressed as a percentage of gross domestic product.

BDPU Domestic public debt securities, expressed as a percentage of gross domestic product.

BIPT International private debt securities, expressed as a percentage of gross domestic product.

BIPU International public debt securities, expressed as a percentage of gross domestic product.

CBMD Composite index of bond market development, using BDPT, BDPU, BIPT, and BIPU.

Definition of Insurance Market Development Variables

ILID

Life insurance density, expressed as direct domestic life premiums per capita.

INID Non-life insurance density, expressed as direct domestic non-life premiums per capita.

ILIP Life insurance penetration, expressed as direct domestic life premiums (as a \% of gross domestic product).

INIP Non-life insurance penetration, expressed as direct domestic non-life premiums (as a \% of gross domestic product).

CIMD Composite index of insurance market development, using ILID, INID, ILIP, and INIP.

Note 1: All monetary measures are in constant price US dollars.

Note 2: All variables above are defined in the World Development Indicators and are published by the World Bank.

Note 3: We use the natural log of these variables in our estimation.

Note 4: Principal component Analysis is used to derive the four composite indices (detailed in the text). 
Table 3. Construction of Financial Development Indices

Principal Components / Variables

Composite index of banking sector development

$\begin{array}{lllll} & \text { Eigenvalues } & \text { \% Variation } & \text { \% Cumulative } & \\ \text { PC1 } & 3.469 & 0.867 & 0.867 & \\ \text { PC2 } & 0.329 & 0.082 & 0.959 & \\ \text { PC3 } & 0.178 & 0.044 & 0.993 & \\ \text { PC4 } & 0.025 & 0.007 & 1.000 & \text { PC4 } \\ & \text { PC1 } & \text { PC2 } & \text { PC3 } & 0.283 \\ \text { BBRM } & 0.502 & 0.179 & 0.797 & -0.621 \\ \text { BDCB } & 0.501 & -0.601 & 0.040 & 0.646 \\ \text { BDCF } & 0.516 & -0.271 & -0.493 & 0.341 \\ \text { BDCP } & 0.480 & 0.730 & -0.346 & \end{array}$

Composite index of stock market development

$\begin{array}{lllll} & \text { Eigenvalues } & \text { \% Variation } & \text { \% Cumulative } & \\ \text { PC1 } & 2.071 & 0.518 & 0.518 & \\ \text { PC2 } & 1.046 & 0.261 & 0.779 & \\ \text { PC3 } & 0.728 & 0.182 & 0.961 & \\ \text { PC4 } & 0.156 & 0.039 & 1.000 & \\ & \text { PC1 } & \text { PC2 } & \text { PC3 } & \text { PC4 } \\ \text { SMAC } & 0.418 & 0.740 & 0.198 & -0.488 \\ \text { STRA } & 0.652 & 0.050 & 0.221 & 0.723 \\ \text { STUR } & 0.439 & -0.661 & 0.388 & -0.469 \\ \text { SNLC } & 0.455 & -0.113 & -0.873 & -0.136\end{array}$

Composite index of bond market development

$\begin{array}{lllll} & \text { Eigenvalues } & \text { \% Variation } & \text { \% Cumulative } & \\ \text { PC1 } & 1.689 & 0.422 & 0.422 & \\ \text { PC2 } & 1.023 & 0.256 & 0.678 \\ \text { PC3 } & 0.953 & 0.238 & 0.916 & \\ \text { PC4 } & 0.333 & 0.084 & 1.000 & \\ & \text { PC1 } & \mathbf{P C 2} & \mathbf{P C 3} & \text { PC4 } \\ \text { BDPT } & 0.701 & -0.028 & 0.001 & -0.712 \\ \text { BDPU } & 0.318 & 0.586 & 0.686 & 0.291 \\ \text { BIPT } & 0.537 & 0.194 & -0.635 & 0.521 \\ \text { BIPU } & 0.344 & 0.787 & -0.355 & -0.370\end{array}$

Composite index of insurance market development

\begin{tabular}{|c|c|c|c|c|}
\hline & Eigenvalues & $\%$ Variation & $\%$ Cumulative & \\
\hline PC1 & 2.835 & 0.709 & 0.709 & \\
\hline PC2 & 0.890 & 0.222 & 0.931 & \\
\hline PC3 & 0.236 & 0.059 & 0.990 & \\
\hline \multirow[t]{2}{*}{ PC4 } & 0.039 & 0.010 & 1.000 & \\
\hline & PC1 & PC2 & PC3 & PC4 \\
\hline ILID & 0.469 & -0.584 & 0.527 & -0.400 \\
\hline INID & 0.487 & 0.538 & 0.512 & 0.460 \\
\hline ILIP & 0.520 & -0.418 & -0.528 & 0.525 \\
\hline INIP & 0.521 & 0.441 & -0.426 & -0.594 \\
\hline
\end{tabular}

Note 1: All variables are defined in Table 2.

Note 2: PC1: Principal Component 1; PC2: Principal Component 2; PC3: Principal Component 3; and PC4: Principal Component 4. 


\section{Variables}

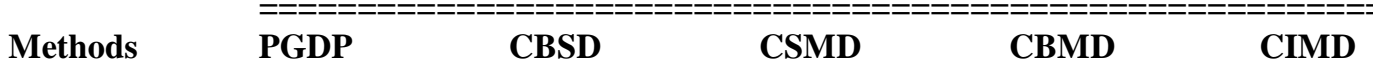

\section{Sample 1: ARF member and observer countries (AMOC)}

Group 1- Null: Unit root (assumes common unit root process)

$\begin{array}{lllllllll}\mathbf{L L C} & -7.40^{*} & {[0.00]} & -2.36^{*}[0.00] & -4.57 *[0.00] & -5.53 * & {[0.00]} & -2.54 * & {[0.00]} \\ \mathbf{B R} & -6.89 * & {[0.00]} & -1.93 * *[0.05] & -4.73 *[0.00] & -3.43 * & {[0.00]} & -3.53 * & {[0.00]}\end{array}$

Group 2- Null: Unit root (assumes individual unit root process)

$\begin{array}{lllllllllll}\text { IPS } & -4.64 * & {[0.00]} & -1.25^{* * *}[0.10] & -2.68^{*} & {[0.00]} & -2.98^{*} & {[0.00]} & -2.29 * & {[0.00]} \\ \text { ADF } & 64.78^{*} & {[0.00]} & 22.1 * * *[0.10] & 40.0^{*} & {[0.00]} & 39.0^{*} & {[0.00]} & 23.47 * & {[0.00]} \\ \text { PP } & 268.9 * & {[0.00]} & 35.8^{*} & {[0.00]} & 85.1 * & {[0.00]} & 110.4 * & {[0.00]} & 41.73^{*} & {[0.00]} \\ \text { Inference: } & \mathrm{I}(1) & & \mathrm{I}(1) & & \mathrm{I}(1) & & \mathrm{I}(1) & & \mathrm{I}(1) & \end{array}$

\section{Sample 2: ARF dialogue partner countries (ADPC)}

Group 1- Null: Unit root (assumes common unit root process)
LLC$$
-4.62 * \quad[0.00]
$$$$
-2.28 *[0.00]-8.17 *[0.00]
$$
$-9.72 *$
[0.00]
$-1.44 * * *[0.10]$
BR$$
-3.81 * \quad[0.00]
$$
$-2.17 * *[0.00]$
$-2.58 * \quad[0.00]$
$-1.51 * * *[0.10]-1.23 * * *[0.10]$

Group 2- Null: Unit root (assumes individual unit root process)

\begin{tabular}{|c|c|c|c|c|c|c|c|c|}
\hline IPS & $-6.89 *$ & {$[0.00]$} & $-1.92 * *[0.05]$ & $-7.74 *$ & {$[0.00]$} & $-6.66^{*}$ & {$[0.00]$} & $-1.29 * * *[0.10]$ \\
\hline ADF & $77.4^{*}$ & {$[0.00]$} & $29.59 * * *[0.10]$ & $79.95^{*}$ & {$[0.00]$} & $66.34 *$ & {$[0.00]$} & $23.89 * *[0.05]$ \\
\hline $\mathbf{P P}$ & $593.0 *$ & {$[0.00]$} & $77.30 * \quad[0.00]$ & $133.1 *$ & {$[0.00]$} & $96.44^{*}$ & {$[0.00]$} & $47.77 * \quad[0.00]$ \\
\hline Inference: & $\mathrm{I}(1)$ & & I (1) & I (1) & & I (1) & & I (1) \\
\hline
\end{tabular}

\section{Sample 3: All (total) ARF countries (TARC)}

Group 1- Null: Unit root (assumes common unit root process)
LLC
$-8.37 *[0.00]$
$-3.37 *$
[0.00] $-9.90 * \quad[0.00]$
$-10.3^{*}$
[0.00]
$-2.87 * \quad[0.00]$
BR
$-6.76^{*}[0.00] \quad-2.87 *[0.00] \quad-4.77 * \quad[0.00]$
$-1.38 * * *[0.10]$
$-2.74 *[0.00]$

Group 2- Null: Unit root (assumes individual unit root process)

$\begin{array}{llllllllll}\text { IPS } & -9.71^{*} & {[0.00]} & -2.73^{*} & {[0.00]} & -8.37 * & {[0.00]} & -5.13^{*} & {[0.00]} & -2.22^{*}[0.00] \\ \text { ADF } & 145.2^{*} & {[0.00]} & 54.2^{*} & {[0.00]} & 121.50^{*}[0.00] & 98.7^{*} & {[0.00]} & 47.82^{*}[0.00] \\ \text { PP } & 874.2^{*} & {[0.00]} & 113.2^{*} & {[0.00]} & 217.7^{*} & {[0.00]} & 209.5^{*} & {[0.00]} & 88.48^{*}[0.00] \\ \text { Inference: } & \mathrm{I}(1) & & \mathrm{I}(1) & & \mathrm{I}(1) & & \mathrm{I}(1) & & \mathrm{I}(1)\end{array}$

Note 1: PGDP is the per capita economic growth rate; CBSD is the composite index of banking sector development; CSMD is the composite index of stock market development; CBMD is the composite index of bond market development; CIMD is the composite index of insurance market development.

Note 2: LLC: Levine-Lin-Chu t-statistics; BR: Breitung t-statistics; IPS: Im-Pesaran and Shin W-statistics; ADF: Augmented Dickey Fuller Fisher Chi-square-statistics; and PP: Phillips Perron Chi-square- statistics.

Note 3: The null hypothesis is that the variable follows a unit root process.

Note 4: The statistics are reported at the first difference of the variables only.

Note 5: We have tested the unit root at three levels (no intercept and no trend; deterministic intercept only; and deterministic intercept and trend only); but the reported statistics are for deterministic intercept and trend only.

Note 6: $* *$ indicates significance at a $1 \%$ level, $* *$ indicates significance at a $5 \%$ level, and $* * *$ indicates significance at a $10 \%$ level. 
Table 5. Results of Pedroni Panel Cointegration Test

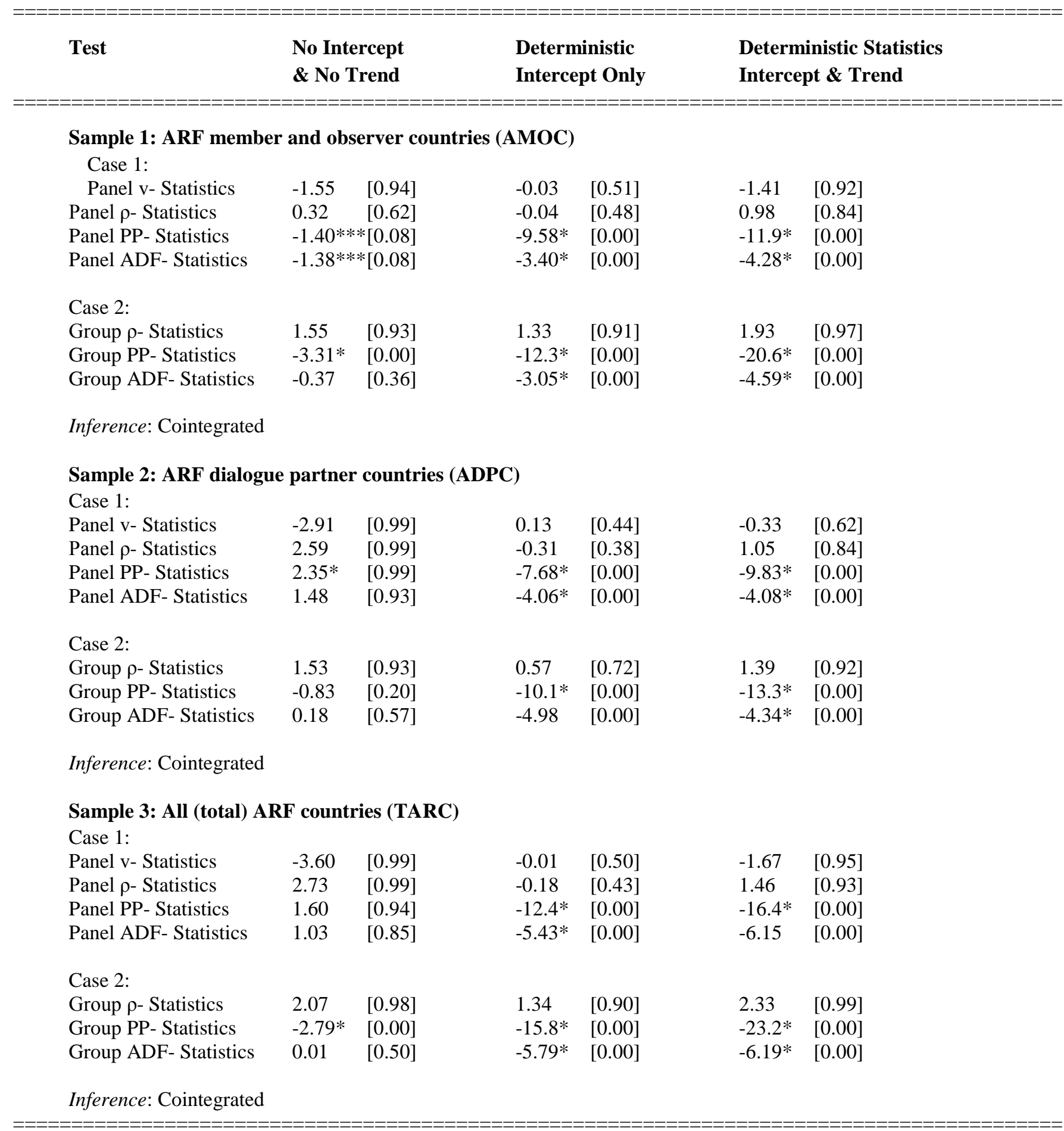

Note 1: Variables and regions shown above are defined in the text.

Note 2: The null hypothesis is that the variables are not cointegrated.

Note 3: Figures in square brackets are the probability levels indicating significance.

Note 4: * indicates significance at a $1 \%$ level; *** indicates significance at a $10 \%$ level.

Note 5: ADF: Augmented Dickey Fuller statistics; and PP: Phillips Perron statistics. Details on these statistics are available in Pedroni (2004). 
Table 6. Granger Causality Test Results

\begin{tabular}{|c|c|c|}
\hline $\begin{array}{l}\text { Dependent } \\
\text { Variable }\end{array}$ & Independent variables & Lagged ECT \\
\hline
\end{tabular}

Sample 1: ARF member and observer countries (AMOC)

$\begin{array}{lllllll} & \Delta \text { PGDP } & \Delta \text { CBSD } & \Delta \text { CSMD } & \Delta \text { CBMD } & \Delta \text { CIMD } & \text { ECT }-1 \\ \Delta \text { PGDP } & -----[-----] & 2.73[0.23] & 8.79 *[0.00] & 5.14 * *[0.05] & 5.83 * *[0.05] & -1.04 *(-6.15) \\ \Delta \text { CBSD } & 3.50 * * *[0.10] & -----[-----] & 4.48^{* * *}[0.10] & 2.49[0.27] & 5.89 * *[0.05] & -0.11(-1.69) \\ \Delta \text { CSMD } & 3.88^{* * *}[0.10] & 6.41 *[0.01] & -----[-----] & 7.25 *[0.01] & 11.0 *[0.00] & -0.15(-0.84) \\ \Delta \text { CBMD } & 3.97 * * *[0.10] & 3.82 * * *[0.10] & 1.72[0.53] & -----[----] & 3.78 * * *[0.10] & -0.08 * *(-5.49) \\ \Delta \text { CIMD } & 10.3 *[0.00] & 2.00[0.27] & 2.56[0.16] & 2.36[0.28] & -----[-----] & -0.04(-1.10)\end{array}$

Sample 2: ARF dialogue partner Countries (ADPC)

$\begin{array}{lllllll} & \Delta \text { PGDP } & \Delta \text { CBSD } & \Delta \text { CSMD } & \Delta \text { CBMD } & \Delta \text { CIMD } & \text { ECT-1 } \\ \Delta \text { PGDP } & -----[-----] & 3.11[0.13] & 12.2 *[0.00] & 15.0 *[0.00] & 3.72 * * *[0.10] & -0.49 * *(-5.62) \\ \Delta \text { CBSD } & 4.05 * * *[0.10] & -----[-----] & 5.68 * *[0.05] & 2.01[0.23] & 0.51[0.71] & -0.09(-1.96) \\ \Delta \text { CSMD } & 2.34[0.25] & 3.49 * * *[0.10] & -----[----] & 2.68[0.22] & 3.94 * * *[0.10] & -0.01(-0.04) \\ \Delta \text { CBMD } & 38.0 *[0.00] & 4.07 * * *[0.10] & 5.66 * *[0.05] & -----[----] & 9.00 *[0.01] & -0.72 * *(-5.55) \\ \Delta \text { CIMD } & 4.54 * * *[0.10] & 3.98 * * *[0.10] & 0.98[0.80] & 10.4 *[0.00] & -----[----] & -0.02(-0.54)\end{array}$

Sample 3: All (total) ARF countries (TARC)

$\begin{array}{lllllll} & \Delta \text { PGDP } & \Delta \text { CBSD } & \Delta \text { CSMD } & \Delta \text { CBMD } & \Delta \text { CIMD } & \text { ECT-1 } \\ \Delta \text { PGDP } & -----[-----] & 2.39[0.23] & 14.4 *[0.00] & 4.06 * * *[0.10] & 4.28 * * *[0.10] & -0.70 *(-7.73) \\ \Delta \text { CBSD } & 3.73 * * *[0.10] & -----[-----] & 3.71 * * *[0.10] & 3.89 * * *[0.10] & 1.71[0.33] & -0.10(-1.68) \\ \Delta \text { CSMD } & 3.91 * * *[0.10] & 3.95 * * *[0.10] & -----[-----] & 3.47 * * *[0.10] & 12.4 *[0.00] & -0.08(-0.77) \\ \Delta \text { CBMD } & 17.6 *[0.00] & 4.57 * * *[0.10] & 6.10 *[0.01] & -----[-----] & 7.62 *[0.01] & -0.38 * *(-5.15) \\ \Delta \text { CIMD } & 9.19 *[0.01] & 4.17 * * *[0.10] & 0.35[0.84] & 8.74 *[0.01] & ------[-----] & -0.99(-0.03)\end{array}$

Note 1: PGDP is the per capita economic growth rate; CBSD is the composite index of banking sector development; CSMD is the composite index of stock market development; CBMD is the composite index of bond market development; CIMD is the composite index of insurance market development, $\mathrm{ECT}_{-1}$ is the lagged error-correction term.

Note 2: The figures in round brackets are $t$-statistics; the figures in square brackets contain the level of probability.

Note 3: *, ** and $* * *$ indicate that the parameter estimates are significant at $1 \%, 5 \%$ and $10 \%$ levels, respectively. 
Table 7. Summary of Short-run Granger Causality Results

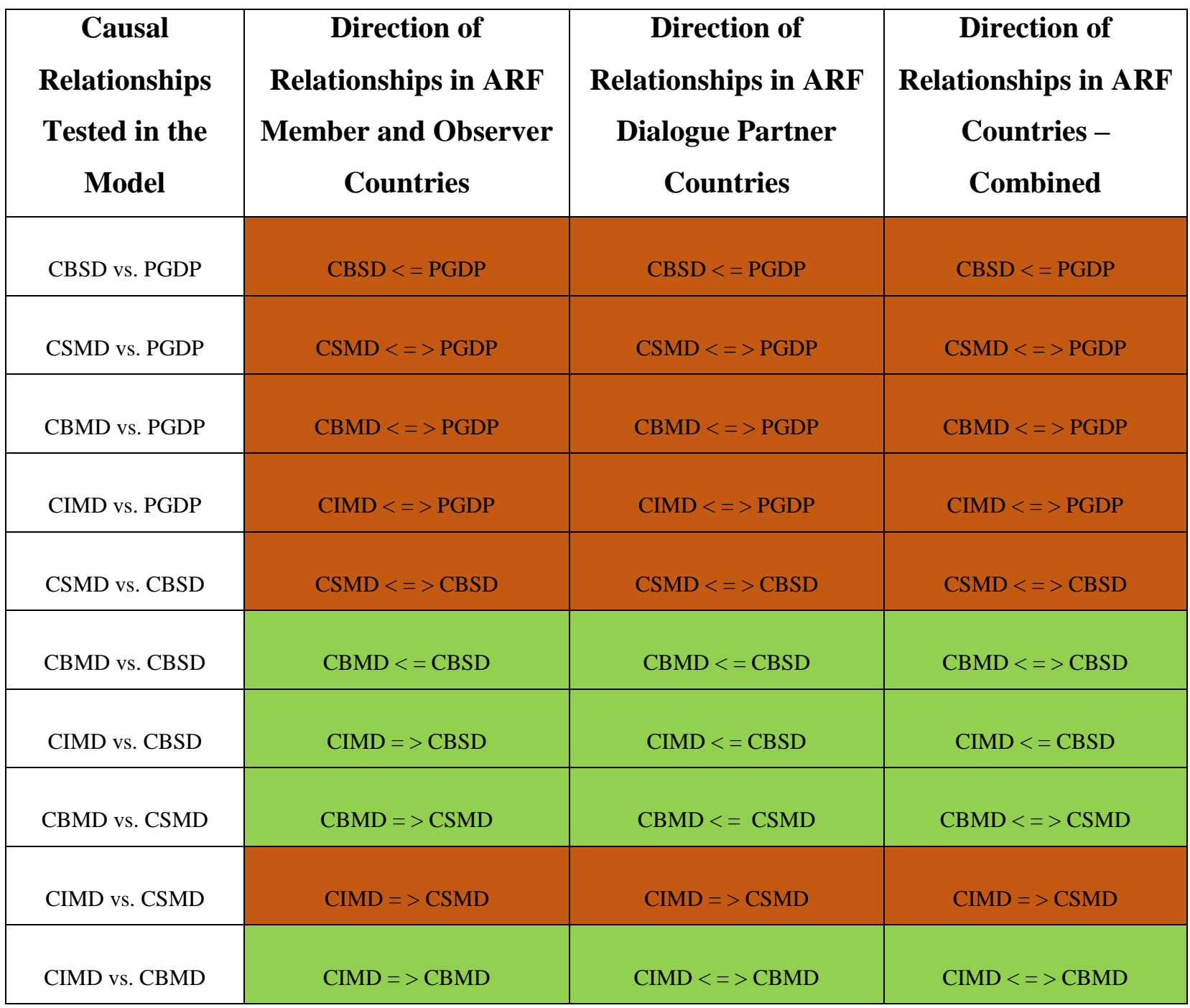

Note 1: PGDP is the per capita economic growth rate; CBSD is the composite index of banking sector development; CSMD is the composite index of stock market development; CBMD is the composite index of bond market development; CIMD is the composite index of insurance market development. Variables are defined more precisely in Table 2.

Note 2: $\mathrm{X}=>\mathrm{Y}$ means variable $\mathrm{X}$ Granger-causes Variable $\mathrm{Y}, \mathrm{X}<=\mathrm{Y}$ means variable $\mathrm{Y}$ Granger-causes Variable $\mathrm{X}$, and $\mathrm{X} \ll=>\mathrm{Y}$ means both variables Granger-cause each other. 


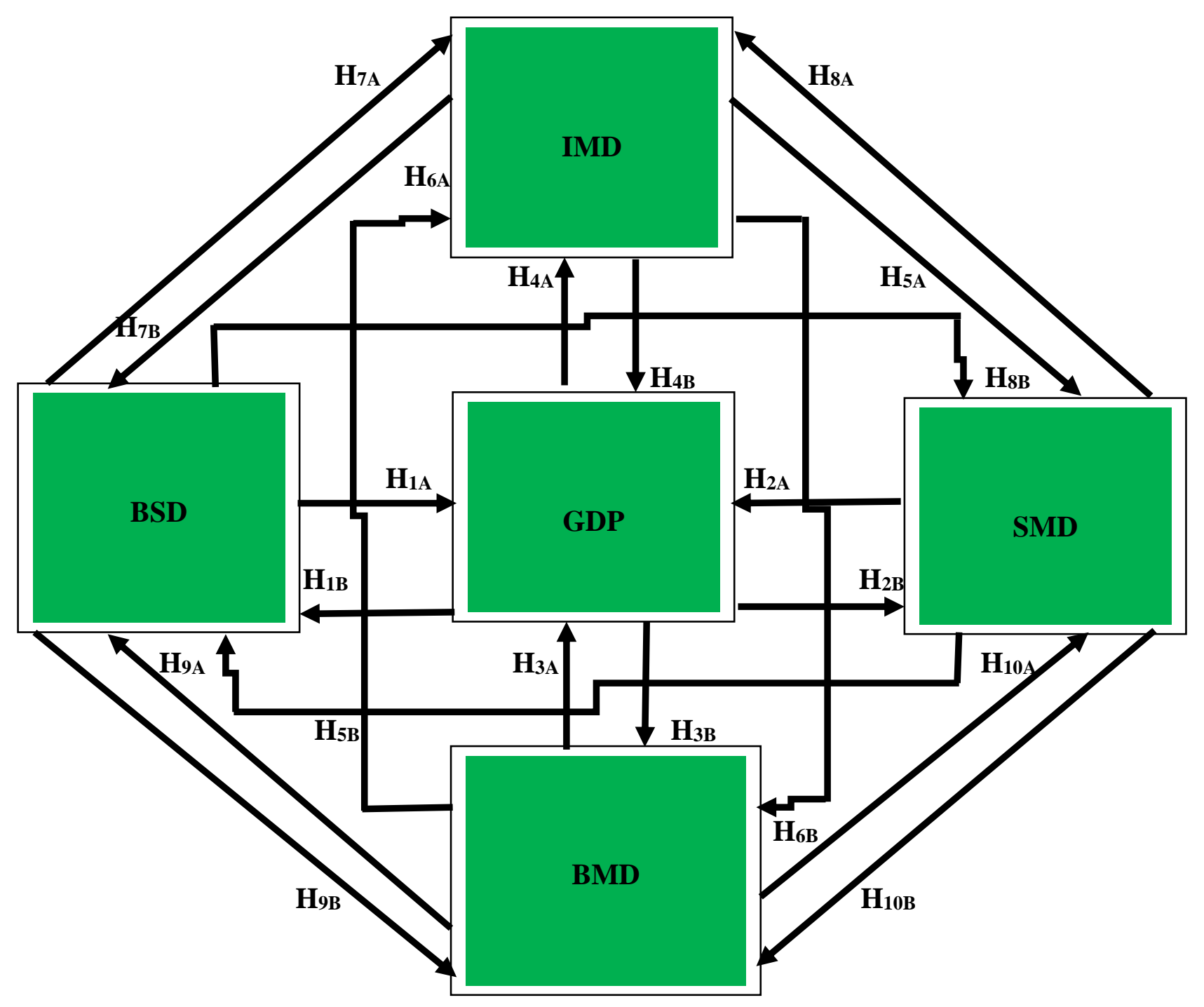

Note 1: PGDP is the per capita economic growth rate; CBSD is banking sector development; CSMD is stock market development; CBMD is bond market development; CIMD is insurance market development.

Note 2:

$\mathrm{H}_{1 \mathrm{~A}, \mathrm{~B}}$ : Banking sector development Granger-causes economic growth and vice versa.

$\mathrm{H}_{2 \mathrm{~A}, \mathrm{~B}}$ : Stock market development Granger-causes economic growth and vice versa.

$\mathrm{H}_{3 \mathrm{~A}, \mathrm{~B}}$ : Bond market development Granger-causes economic growth and vice versa.

$\mathrm{H}_{4 \mathrm{~A}, \mathrm{~B}}$ : Insurance market development Granger-causes economic growth and vice versa.

$\mathrm{H}_{5 \mathrm{~A}, \mathrm{~B}}$ : Banking sector development Granger-causes stock market development and vice versa.

$\mathrm{H}_{6 \mathrm{~A}, \mathrm{~B}}$ : Bond market development Granger-causes insurance market development and vice versa.

$\mathrm{H}_{7 \mathrm{~A}, \mathrm{~B}}$ : Banking sector development Granger-causes insurance market development and vice versa.

$\mathrm{H}_{8 \mathrm{~A}, \mathrm{~B}}$ : Stock market development Granger-causes insurance market development and vice versa.

$\mathrm{H}_{9 \mathrm{~A}, \mathrm{~B}}$ : Bond market development Granger-causes banking sector development and vice versa.

$\mathrm{H}_{10 \mathrm{~A}}$, : Bond market development Granger-causes stock market development and vice versa.

Figure 1. Various Hypotheses on the Possible Causal Flows between Different Aspects of Financial Development and Economic Growth 